\title{
化学溶液法により作製した銅含有シリカ膜の耐腐食性及び抗菌性
}

\author{
小野さとみ・柘植弘安・松田淑美* ·小川和男* \\ 名古屋市工業研究所, 456-0058 名古屋市熱田区六番 3-4-41 \\ *岡崎国立共同研究機構アイソトープ実験センター，444-8585 岡崎市明大寺町字東山 5-1
}

\section{Corrosion Resistance and Antimicrobial Activity of Copper-Containing Silica Films Prepared by Chemical Solution Deposition}

\author{
Satomi ONO, Hiroyasu TSUGE, Yoshimi MATSUDA* and Kazuo OGAWA* \\ Nagoya Municipal Industrial Research Institute, 3-4-41, Rokuban, Atsuta-ku, Nagoya-shi 456-0058 \\ *Okazaki National Research Institute Center for Radioisotope Facilities, 5-1, Higashiyama, Myodaiji-cho, Okazaki-shi 444-8585
}

\begin{abstract}
Films were prepared on stainless steel, aluminum alloy and glass substrates using silica precursor solution containing copper ions. The thickness of the film coating was about 0.1-0.2 $\mu \mathrm{m}$. The corrosion resistance was greatly improved by PVB-containing silica coating onto stainless steel. An antimicrobial test based on Japanese Industrial Standard (JIS Z 2801) indicates that the antimicrobial activity $(R)$ of a control silica coating is $R=0.0$, whereas $R=5.0$ for the copper-containing silica coating $\left(\mathrm{Cu}: 6.1 \times 10^{-3} \mathrm{~mol} / \mathrm{L}\right)$. JIS defines antimicrobial activity as positive when $R$ is more than 2.0. A submicron thick copper-containing silica coating clearly impacts corrosion resistance and antimicrobial activity to a material surface without any heat treatment. [Received May 13, 2003; Accepted June 25, 2003]
\end{abstract}

Key-words : Chemical solution deposition, Copper, Silica coating, Corrosion resistance, Antimicrobial activity

\section{1. 緒 言}

これまで，ステンレス，アルミニウムやアルミニウム合金の 表面処理としてクロメートが用いられてきたが，最近では，ク ロムが環境に悪い影響をもたらすことよりクロム $\left(\mathrm{Cr}^{6+}, \mathrm{Cr}^{3+}\right)$ フリーの化成処理方法の開発の要求が高まっている. 一方，セ ラミックスコーティングは金属の耐腐食性，耐熱性や耐磨耗性 を向上させる有効な手段である．セラミックスコーティングに はプラズマスプレー1)，陽極酸化， $\mathrm{PVD}^{2)}$ や化学溶液法3) 13)な ぞの方法があるが，その中でも化学溶液法は最も産業化に適し ている.なぜなら，多種多様な形状の大面積の表面に対して， 均一なコーティング膜が低温において省エネ的に作製できる安 価な方法だからである．著者らは環境負荷を与えないエタノ一 ルや水を溶媒とした化学溶液を用いて，環境に優しい低温プロ セスにより付加価值の高い機能性セラミックス材料の合成を行 うための技術開発をめざしている。これまでに，ステンレスや アルミニウム合金等の金属表面上にサブミクロンオーダーの密 着性の優れたシリカ膜を作製することにより，金属表面の耐腐 食性を向上させることができた ${ }^{14)}$.

ところで，最近では生活環境に対する感心が高まり，清潔指 向や病院に抢ける院内感染の防止など社会において抗菌性に対 するニーズが高まっている，抗菌材料は，大きく有機系と無機 系に分けることができるが，耐熱性や化学的安定性に優ってい る無機系材料が注目されている，無機系抗菌剤としては，ゼオ ライトに銀，銅，亜鉛などの抗菌性を有する金属イオンを坦持 した抗菌性ゼオライト ${ }^{15)}$ ，アパタイトを二酸化チタンに被覆 したアパタイト付着セラミックス複合抗菌剂16)などが報告さ れている．また，ゾルーゲル法を用いて作製した銀とアルミニ ウを含有するシリカガラスにおいては $\mathrm{Al} / \mathrm{Ag} \gg 1$ とすることに より銀イオンが徐々に放出されるように制御できる17).

そこで，本研究では耐腐食性を有するシリカコーティングに 更に抗菌性を付与することを目的として，抗菌剂として安価な 金属である銅を複合化し，低温で作製が可能である耐腐食性 抗菌シリカコーティング技術の開発を行った.

\section{2. 実 験}

\section{1 前駆体溶液及びコーティング膜の作製}

図 1 に溶液の調製法を示した. シリカコーティング溶液はテ トラエトキシシラン $\left(\mathrm{Si}(\mathrm{OEt})_{4}\right.$, 信越化学製), 酶酸, 水を出 発溶液に抢けるモル比として $1: 3: 4$ でエタノールに溶解し $80^{\circ} \mathrm{C}$ 以下で加熱濃縮することにより調製した。抗菌剤として 銅粉末 ( $<63 \mu \mathrm{m}$, メルク ) を溶液中に溶解させた後, 溶解し ないで残った銅粉末を沪過で取り除いて銅含有シリカコーティ ング溶液を作製した．ポリビニルブチラール2000 (PVB) を 添加する場合は 1 mass \% PVBのエタノール溶液を調製し所定 の濃度になるように添加した。PVBを選んだ理由はエタノー ルに直接溶解する高分子の添加剤は少なく, 調べた中ではエタ ノールに可溶であるPVBが最も適していると考えて選択し た. 溶液中のケイ素及び銅の濃度は ICP 発光分析法（ICP）で 分析した.

コーティング膜はステンレス (SUS304), アルミ合金 (ADC

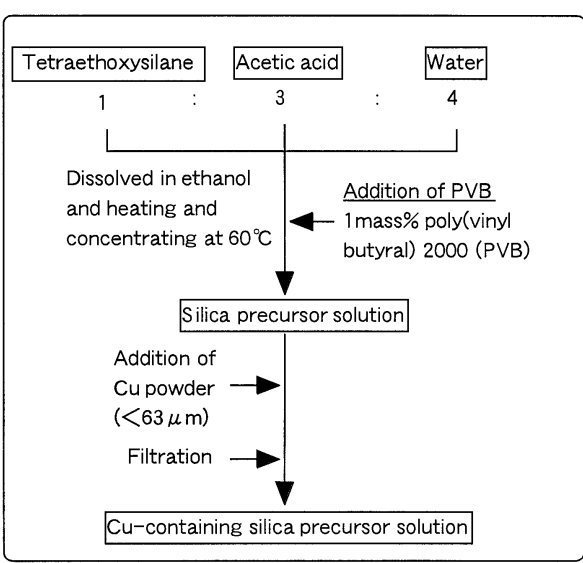

Fig. 1. Preparation procedure of precursor solutions. 
12)，スライドグラス (岩城硝子製) 基板上にディップコーティ ングにより作製した.コーティング後, 常温下において乾燥す るか又は $200^{\circ} \mathrm{C} て ゙ ~ 1 \mathrm{~h}$ 加熱処理した。

加熱処理温度を $200^{\circ} \mathrm{C}$ とた理由としては, PVBの熱分解 温度が $260^{\circ} \mathrm{C}$ 以上であることや，SUS304 基板上に作製した コーティング膜について, 常温乾燥した場合と $200^{\circ} \mathrm{C}$ で $1 \mathrm{~h}$ 加 熱処理した場合で耐腐食性を調べたところ, 同程度の耐腐食性 を有していたことより，膜中の PVBによるバリヤー性が失わ れることがなく劣化しない温度として $200^{\circ} \mathrm{C}$ と決定した。

\section{2 溶液の組成・濃度と膜厚の関係}

ディップコーティング法により製膜する場合，作製膜の膜厚 は溶液の粘性, 組成・濃度や引き上げ速度に大きく依存する.

特に溶液濃度を高くしたり, 引き上げ速度を速くすることによ り膜厚は厚くなる，そこで，まず，組成や濃度の異なる前駆体 溶液を調製し，スライドグラス基板上にコーティングを行っ た．その作製膜の表面及び断面を走査型電子顕微鏡 (SEM) で観察することにより製膜状態や膜厚を調べた.

\section{3 コーティング試料の評価}

コーティング膜の基板への密着性はスコッチテープによる ピーリングテストにより調ベた．コーティング膜の硬度の評価 は表面研磨した ADC12 基板上に約 $1 \mu \mathrm{m}$ の厚さにコーティン グした試料の表面硬度を薄膜測定用の微小硬度測定装置（アカ シ MZT-3）により測定して行った.

耐腐食性の評価は塩化第二鉄腐食試験（JIS G 0578）に準 じて行った，腐食率はコーティング試料を $6 \%$ 塩化鉄溶液中に $50^{\circ} \mathrm{C}$ で $17 \mathrm{~h}$ 浸漬した後の単位面積 ・時間当たりの重量減少で ある. 本論文ではコーティングしていないステンレス基板の腐 食率を $100 \%$ としてコーティング試料の腐食率を計算した。

抗菌性の評価は, 銅を含まないシリカコーティングしたスラ イドグラスをコントロールとして, 日本工業規格, 抗菌加工製 品-抗菌性試験方法・抗菌効果（JIS Z 2801）に基づいて，大 腸菌（Escherichia coli, IFO3972, 財団法人発酵研究所）に対 する抗菌試験を行った。

\section{3. 結果及び考察}

\section{1 溶液の組成 ·濃度と膜厚の関係}

溶液の組成では酢酸及び水の添加量により製膜性に著しい違 いが生じた．テトラエトキシシランに対して水を全く添加しな い場合は製膜可能な溶液を調製できなかった. 1 モル量のテト ラエトキシシランに対して水を 4 モル量添加した場合は酢酸 を 3 モル量添加しないと, 均一な透明膜は作製できなかっ た。また, 酢酸の添加量を 1 モル量に減らした場合, 均一な
透明膜を作製するためには20モル量の水を添加することが必 要であることが分かった．これらの溶液を用いてコーティング 後, 常温下で 1 日乾燥した作製膜について SEM 観察を行った ところ, 膜表面には亀裂や欠陥は見られず均質で平滑であり, 約 $0.8 \mathrm{~mol} / \mathrm{L}$ の溶液を用いて作製したときのコーティング膜の 膜厚は $0.14 \sim 0.18 \mu \mathrm{m}$ であった. 以上の結果より, 表 1 に示し た No. 1 及びNo. 3 の組成がコーティングに適していることが 分かった. しかしながら, 長期保存性に関してはNo. 1 の溶液 の方が水を多く含有するNo. 3 の溶液よりも優れており, ゲル 化することなく数力月間の保存が可能であった.

\subsection{ADC12 上に作製したコーティング膜の硬度}

No. 1 の溶液を用いて ADC12 基板上にコーティングした場 合, 常温での乾燥後に表面が疎水性になり, 2 回目以降のコー ティングが困難であったため, コーティングを重ねて行う場合 にはコーティング後に $200^{\circ} \mathrm{C} て ゙$ 加熱処理を行う必要がある.こ れは, 抢そらく溶液を加熱濃縮する過程でテトラエトキシシラ ンと酢酸の反応によりテトラエトキシシランがアセチル化さ れ, 常温乾懆ではそのアセチル基が膜表面にあって疎水性が高 くなり，2 回目のコーティング時に溶液に対するぬれが悪くな るのではないかと考えている. No. 3 の溶液を用いてコーティ ングをする場合, 常温 1 日乾燥では, 引き上げ速度 $4.2 \mathrm{~mm} / \mathrm{s}$ で 2 回コーティングすることにより，スコッチテープによる ピーリングによってはく離することのない $1.1 \mu \mathrm{m}$ のシリカ膜

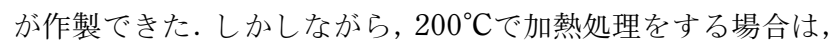
1 回で製膜可能な膜厚は引き上げ速度 $2.1 \mathrm{~mm} / \mathrm{s}$ でのコーティ ングによる $0.36 \mu \mathrm{m}$ 程度が加熱処理後にはく離しない限界であ ることが分かった．そこで，その引き上げ速度 $2.1 \mathrm{~mm} / \mathrm{s}$ での コーティング及び加熱処理を 3 回繰り返すことによって, 1.1 $\mu \mathrm{m}$ のシリカ膜を作製した．その作製膜の表面を SEM で観察 した結果, 多数の亀裂が生じていることが分かった（図 2

Table 1. Relation between Composition of Precursor Solution and Film Thickness

\begin{tabular}{|c|c|c|c|c|c|c|}
\hline No. & \multicolumn{3}{|c|}{$\begin{array}{c}\text { Composition } \\
\text { (Molar ratio) }\end{array}$} & $\begin{array}{c}\text { Conc. } \\
\text { (mol/L) }\end{array}$ & Coating film & $\begin{array}{c}\text { Thickness } \\
/ \text { single } \\
\text { coating } \\
(\mu \mathrm{m})\end{array}$ \\
\cline { 2 - 6 } & Si(OEt) 4 & $\begin{array}{c}\text { Acetic } \\
\text { acid }\end{array}$ & Water & & & - \\
\hline 0 & 1 & 3 & 0 & 1.7 & $\mathrm{X}$ & - \\
\hline 1 & 1 & 3 & 4 & 0.77 & $\begin{array}{c}\text { ( } \\
\text { Transparent }\end{array}$ & 0.14 \\
\hline 2 & 1 & 1 & 10 & 0.71 & $\begin{array}{c}\triangle \\
\text { Transparent }\end{array}$ & - \\
\hline$\underline{3}$ & 1 & 1 & 20 & 0.79 & $\begin{array}{c}\text { O } \\
\text { Transparent }\end{array}$ & 0.18 \\
\hline
\end{tabular}

(O) : excellent, $\triangle$ : bad, $X$ : unable to be coated

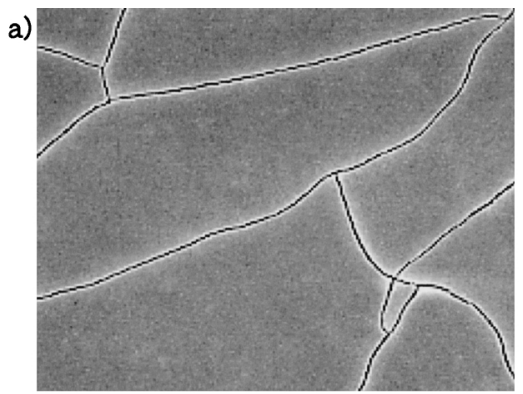

$\overline{10 \mu \mathrm{m}}$ b)

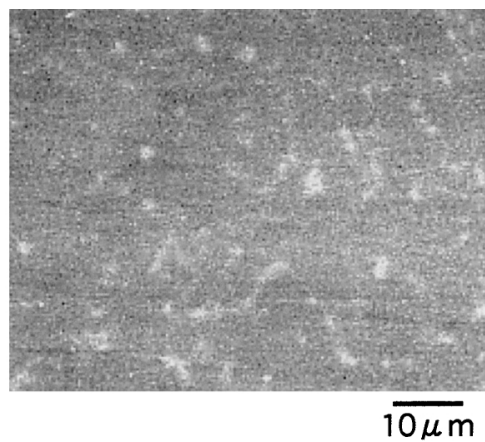

c)

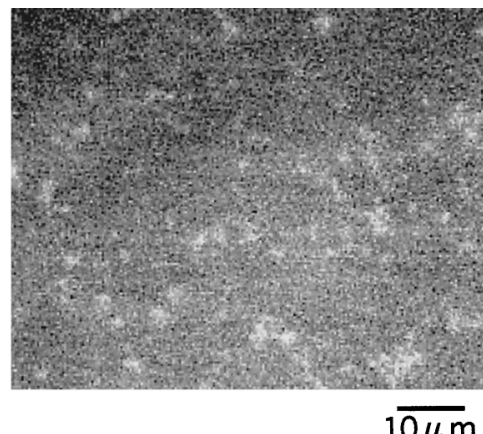

Fig. 2. SEM photographs of a) silica coating, b) PVB-containing silica coating and c) PVB and copper-containing silica coating on ADC12 substrates. 
Table 2. Micro-Vickers Hardness of Silica Films Coated on $\mathrm{ADC} 12$

\begin{tabular}{|c|c|c|}
\hline Sample & $\begin{array}{c}\text { Heat-treatment } \\
\text { Temp. }\left({ }^{\circ} \mathrm{C}\right)\end{array}$ & $\begin{array}{c}\text { Hardness (HUV) } \\
\left(\mathrm{mN} / \mu \mathrm{m}^{2}\right)\end{array}$ \\
\hline ADC12 substrate & - & $126 \pm 13$ \\
\hline Silica coating (No.3) & $\begin{array}{c}\text { Room temp. } \\
\text { Silica coating (No.3) }\end{array}$ & $141 \pm 5$ \\
\hline $\begin{array}{c}\text { Silica coating } \\
\text { (No.1+0.5mass\% PVB) }\end{array}$ & 200 & $134 \pm 1$ \\
$\begin{array}{c}\text { Copper-containing silica coating } \\
\text { (No.1+0.5mass\% PVB) }\end{array}$ & 200 & $83 \pm 6$ \\
\hline
\end{tabular}

*Film thickness: $1.1 \mu \mathrm{m}$

Table 3. Corrosion Rates of Silica Films Coated on SUS304 (JISG0578)

\begin{tabular}{|c|c|c|}
\hline Sample & $\begin{array}{c}\text { Time for dry } \\
\text { (day) }\end{array}$ & $\begin{array}{c}\text { Corrosion } \\
\text { rates (\%) }\end{array}$ \\
\hline SUS304 substrate & - & 100 \\
\hline Silica coating (No.1) & 3 & $40 \pm 6$ \\
Copper-containing silica coating (No.1) & 3 & $44 \pm 1$ \\
\hline $\begin{array}{c}\text { Silica coating } \\
\text { (No.1+0.5mass\% PVB) }\end{array}$ & 5 & $13 \pm 7$ \\
$\begin{array}{c}\text { Copper-containing silica coating } \\
\text { (No.1+0.5mass\% PVB) }\end{array}$ & 5 & $13 \pm 2$ \\
\hline
\end{tabular}

(a)).これはシリカ膜の熱膨張係数に比べて $\mathrm{ADC} 12$ 基板の熱 膨張係数が大きいため加熱処理に伴う基板の熱膨張・収縮によ り起きると考えられる．そこで，この基板の熱澎張・収縮によ る影響を緩和するためにコーティング溶液中に有機高分子であ る PVB を0.5 mass\%添加したところ，加熱処理後にも亀裂の 生じない平滑な膜を作製することができた（図 $2(\mathrm{~b}))$. 溶液に 銅を添加した場合においても同様な結果であった（図 $2(\mathrm{c}))$.

表 2 にシリカ膜の硬度を測定した結果を示した．No. 3 の溶 液を用いて作製した常温乾燥の試料及び $200^{\circ} \mathrm{C}$ 加熱処理の試料 のビッカース硬度はほぼ同じ值を示し，基板のみの值よりも高 い值であった。一方，No. 1 に0.5 mass\% PVBを添加した溶液 を用いて作製した膜の表面硬度はNo. 3 の溶液を用いて作製し た試料に対して $11 \%$ 程度低下した。また，その溶液に銅イオ ンを含有させることで更にその作製膜の表面硬度は約 $30 \%$ 低 下した. いずれの場合も, 膜中に有機高分子や銅イオンが分散 することにより膜がやわらかくなったためであると考えられ る.

\section{3 耐腐食性の評価}

表 3 にNo. 1 の溶液における 0.5 mass\% PVB 及び銅の添加 の有無がコーティング試料の耐腐食性にどのような影響を与え るかを調べた結果を示す．PVBを添加することにより，耐腐 食性は $30 \%$ 程度高くなり $80 \%$ 以上の耐腐食性の向上を示し た。 また，溶液中に 0.5 mass \% PVB 及び銅を添加しても作製 試料の腐食率はほとんど変わらず耐腐食性には影響を与えない ことが分かった。

\section{4 銅含有シリカコーティング膜の作製及び抗菌性の評価}

銅のシリカコーティング溶液への溶解性は非常に低く, 0.5 mass \% PVB 添加したシリカ前駆体溶液中（ $0.5 \mathrm{~mol} / \mathrm{L} ）$ に溶 解した銅イオンの濃度は常温下での飽和状態に打いて $1.9 \times$ $10^{-2} \mathrm{~mol} / \mathrm{L}$ 程度であった. 図 3 に常温乾燥後のコーティング 膜表面の SEM 写真を示す。銅含有シリカ膜の表面には欠陥は 見られず平滑であり，1回のコーティングにより作製できる膜 厚も銅を含有しない場合とほとんど变わりはなかった．銅イ才
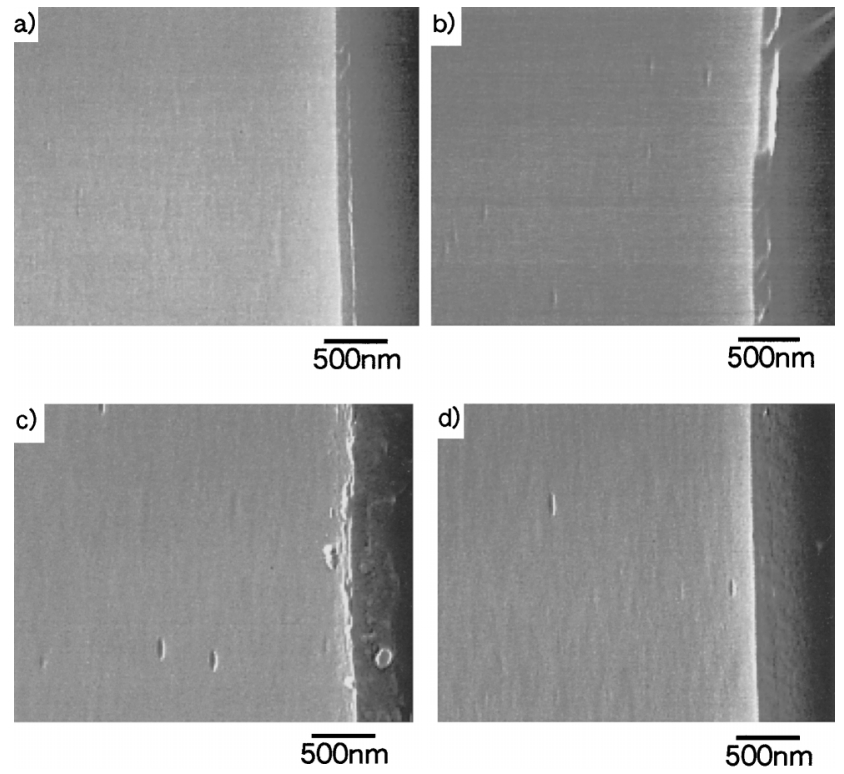

Fig. 3. SEM photographs of a) silica coating, b) copper-containing silica coating, c) PVB-containing silica coating and d) PVB and copper-containing silica coating on glass substrates.

ソ濃度の抗菌性に対する依存性を調べるため, 銅濃度を变えて $\left(3.0 \times 10^{-3}, 6.1 \times 10^{-3}, 1.9 \times 10^{-2} \mathrm{~mol} / \mathrm{L}\right)$ 作製したコーティ ング試料の抗菌試験後のコロニー形成の様子を図 4 に示す。銅 の含有濃度が $6.1 \times 10^{-3} \mathrm{~mol} / \mathrm{L}$ でコロニーの形成はほとんど見 られず, $1.9 \times 10^{-2} \mathrm{~mol} / \mathrm{L}$ ではコロニー数は 0 であった. コー ティング後 $200^{\circ} \mathrm{C}$ で加熱処理した試料についても同様に抗菌性 を示すことを確認した.これらの抗菌試験の結果を表 4 にまと めた. 抗菌性の指標となる抗菌活性值 $(R)$ はコントロールの シリカコーティングで $R=0.0$, 銅含有シリカコーティング $\left(\mathrm{Cu} \geqq 6.1 \times 10^{-3} \mathrm{~mol} / \mathrm{L}\right)$ で $R \geqq 5.0$ を示した. JIS Z 2801 の 規定では, 抗菌効果とは抗菌活性值 2.0 以上であることが定義 されている.よって, 加熱処理を要しないサブミクロンオー ダーの銅含有シリカコーティングにより, 材料表面に抗菌性を 付与できることが明らかになった．

一方，コーティング膜中に含まれている PVB はアルコール 類, ケトン類, エステル類等に可溶であるため, その膜の有機 溶媒に対する耐薬品性は低いと思われるが, 銅イオンによる抗 菌性を有効に発現させるためには水溶液中で利用することが望 ましいと考えている.

\section{4. 結 論}

（1）シリカコーティング溶液の組成・濃度とその溶液を用 いて作製したコーティング膜の膜厚との関係を調べることによ り, 1 回のコーティングで $0.1 \sim 0.2 \mu \mathrm{m}$ の厚さの製膜に適した 溶液の作製条件を確立した。

（2） ADC12 基板上にコーティングする場合には，溶液中 に0.5 mass\% PVB を添加することにより密着性が良く亀裂の 無い平滑なシリカ膜を作製することに効果的であることが分 かった.

（3）金属（SUS304, ADC12）表面に作製したシリカ膜に ついて表面硬度や耐腐食性を評価した結果, 常温乾燥により密 着性及び強度を有したシリカ膜を作製することができ, 耐腐食 性も向上させることができた.

（4）銅イオンの濃度を変えて調製した前駆体溶液からガラ 
a)

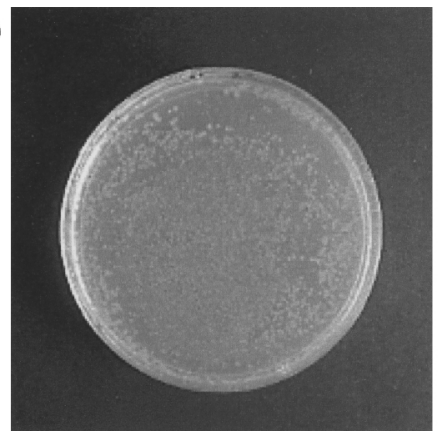

b)

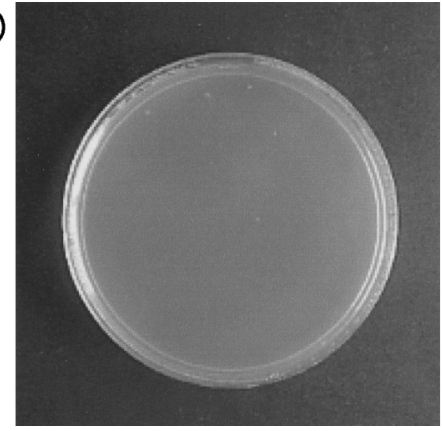

c)

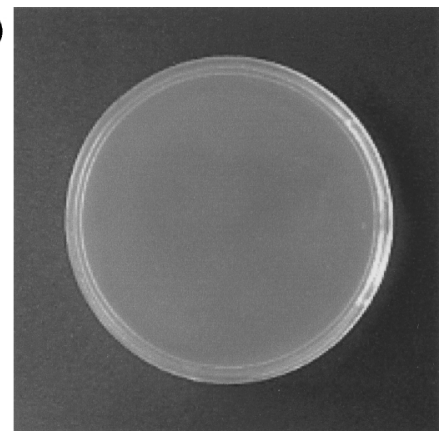

Fig. 4. Photographs of colonies after the test for antimicrobial activity and efficacy in PVB and copper-containing silica coating, a) $3.0 \times$ $\left.10^{-3} \mathrm{~mol} / \mathrm{L},(R: 0.7), \mathrm{b}\right) 6.1 \times 10^{-3} \mathrm{~mol} / \mathrm{L}(R: 5.0)$ and c) $1.9 \times 10^{-2} \mathrm{~mol} / \mathrm{L}(R: \infty)$.

Table 4. Test for Antimicrobial Activity and Efficacy

\begin{tabular}{|c|c|c|}
\hline $\begin{array}{c}\text { Cu concentration } \\
\text { (mol/L) }\end{array}$ & $\begin{array}{c}\text { Antimicrobial activity } \\
(\mathrm{R})\end{array}$ & Efficacy \\
\hline 0 & 0 & No \\
\hline $3.0 \times 10^{-3}$ & 0.7 & No \\
\hline $6.1 \times 10^{-3}$ & 5.0 & Yes \\
\hline $1.9 \times 10^{-2}$ & $\infty$ & Yes \\
\hline
\end{tabular}

$R=\log (A / B)$

A: Average cell number of living E. Coli on control after $24 \mathrm{~h}$.

$B$ : Average cell number of living E. Coli on coated sample after $24 \mathrm{~h}$.

R>2.0, Antimicrobial active

ス基板上に作製したシリカコーティング膜について抗菌性を調 ベたところ， $6.1 \times 10^{-3} \mathrm{~mol} / \mathrm{L}$ 以上という低濃度の銅イオンの 含有により抗菌性を発現することが分かった.

（5）微量の銅イオンをシリカ膜に含有させることにより耐 腐食性及び抗菌性を併わせ持ち, 加熱処理を必要としない簡易 な抗菌コーティングが可能であることが明らかになった。

\section{(2002年12月第 6 回生体関連セラミックス討論会発表)}

\section{References}

1) De Arellano-López, A. R. and Faber, K. T., J. Am. Ceram. Soc., Vol. 82, pp. 2204-2208 (1999).

2) An, K., Ravichandran, K. S., Dutton, R. E. and Semiatin, S. L., J. Am. Ceram. Soc., Vol. 82, pp. 399-406 (1999).

3) De Sanctis, O., Gómez, L., Pellegri, N., Parodi, C., Marajofsky, A. and Durán, A., J. Non-Cryst. Solids, Vol. 121 pp. 338-343 (1990)

4) Izumi, K., Tanaka, H., Murakami, M., Deguchi, T., Morita, A., Tohge, N. and Minami, T., J. Non-Cryst. Solids, Vol. 121, pp. 344-347 (1990).

5) Di Giampaolo Conde, A. R., Puerta, M., Ruiz, H. and Lira Olivares, J., J. Non-Cryst. Solids, Vol. 147 \& 148, pp. 467-473 (1992).

6) Izumi, K., Tanaka, H., Uchida, Y., Tohge, N. and Minami, T., J. Non-Cryst. Solids, Vol. 147 \& 148, pp. 483-487 (1992).

7) Atik, M., Zarzycki, J. and R'kha, C., J. Mater. Sci. Lett., Vol. 13, pp. 266-269 (1994).

8) Atik, M., R'kha, C., De Lima Neto, P., Avaca, L. A., Aegerter, M. A. and Zarzycki, J., J. Mater. Sci. Lett., Vol. 14, pp. 178-181 (1995).

9) Zwinkels, M. F. M., Järås, S. G., Menon, P. G. and Åsen, K. I., J. Mater. Sci., Vol. 31, pp. 6345-6349 (1996).

10) Hirai, S., Shimakage, K., Sekiguchi, M., Wada, K. and Nukui, A., J. Am. Ceram. Soc., Vol. 82, pp. 2011- 2016 (1999).

11) Kirk, P. B. and Pillar, R. M., J. Mater. Sci., Vol. 34, pp. 3967-3975 (1999).

12) Perdomol, L. F., De Lima-Neto, P., Aegerter, M. A. and Avaca, L. A., J. Sol-Gel Sci. Technol., Vol. 15, pp. 87-91 (1999).

13) Messaddeq, S. H., Pulcinelli, S. H., Santilli, C. V., Guastalde, A. C. and Messaddeq, Y., I. Non-Cryst. Solids, Vol. 247, pp. 164-170 (1999).

14) Ono, S., Nishi, Y. and Hirano, S., J. Am. Ceram. Soc., Vol. 84, pp. 3054-3056 (2001).

15) Uchida, M., Chemical Industry, Vol. 9, pp. 736-742 (1995) [in Japanese].

16) Nonami, T., Function \& Materials, Vol. 21, pp. 22-30 (2001) [in Japanese].

17) Kawashita, M., Tsuneyama, S., Miyaji, F., Kokubo, T., Kozuka, H. and Yamamoto, K., Biomaterials, Vol. 21, pp. 393-398 (2000). 